\title{
UNA ESCULTURA DE ALABASTRO PRODUCIDA EN LOS TALLERES DEL MAESTRO DE RÍMINI: LA VIRGEN DE LA PEÑA, EN BETANCURIA (FUERTEVENTURA)
}

\author{
POR \\ Francisco José Galante GómeZ \\ Universidad de La Laguna
}

A mi querida amiga Isabel Mateo Gómez, a su constante generosidad y ejemplar trayectoria científica

En las primeras décadas del siglo XV fueron ejecutadas excelentes esculturas de alabastro en talleres europeos de gran producción, localizados en una zona fronteriza entre el norte de Francia y el sur de los antiguos Países Bajos meridionales, en un área geográfica comprendida entre las ciudades de Lille, Arras y Tournai, y en el bajo y medio Rin. Eran piezas de reducido formato que fueron distribuidas en un amplio mercado gracias a la incesante actividad mercantil. En estos talleres fueron elaboradas obras con características muy afines entre ellas, que han sido adscritas al arcano "Maestro de Rímini". Una de las tipologías de mayor tratamiento fue la "Virgen sedente con Niño", de gran arraigo en la iconografía mariológica, que fue adaptada a una de las variantes del Gótico Internacional, al denominado "estilo suave" o "bello estilo", desarrollado entre 1400 y 1440, aunque con ligeros matices diferenciales. La Virgen de la Peña, que se encuentra en su Santuario de Betancuria (Isla de Fuerteventura. Canarias), corresponde a los prolíferos talleres del "Maestro de Rímini".

Palabras clave: Escultura gótica europea. Esculturas de alabastro. Siglo XV. Maestro de Rímini. Canarias. Fuerteventura. Betancuria. Virgen de la Peña.

During the first decades of the $15^{\text {th }}$ century excellent alabaster sculptures were produced in highly active European workshops located in the frontier region between northern France and the southern Low Countries, in a geographical area comprised by the cities of Lille, Arras and Tournai, and in the lower and middle Rhine. They were small-scale pieces appropriate for distribution to a wide market thanks to continuous mercantile activities. In these workshops sculptures with very similar characteristics were carried out which have been attributed to the so-called "Master of Rimini." One of the most frequent types was the "Virgin Seated with the Christ Child," adapted to the International Gothic or "beautiful style" between 1400 and 1440. The Virgin of the Rock in the Sanctuary of Betancuria (Fuerteventura Island, Canaries), corresponds to the prolific workshops of the "Master of Rimini."

Key words: European Gothic sculpture. Alabaster sculpture. 15 $5^{\text {th }}$ century. Master of Rimini. Canary Islands. Fuerteventura. Betancuria. Virgin of the Rock. 
Como es bien conocido, la utilización del alabastro como material para trabajos plásticos se remonta en Europa al siglo XIV. Especialmente en Inglaterra fueron instalados numerosos talleres de producción que se localizaban en las inmediaciones de los yacimientos de este noble material, de apariencia marmórea y susceptible de hermoso y acabado pulimentado. En efecto, hacia 1350 los activos talleres de Nottingham, sobre todo, York, Liconln, Norwich y Derbyshire, abastecieron de esculturas no sólo al propio país, sino también exportaron en gran escala a la mayor parte de Europa, como Francia, Italia, España y a ciudades pertenecientes a la liga hanseática, cuyos destinatarios más importantes eran iglesias, instituciones religiosas y devotos en general, ávidos por nutrirse de novedosas esculturas de alabastro.

Hacia la última década del siglo XIV estos talleres, coincidiendo con un período álgido de producción, se especializaron en la ejecución de altos relieves que alcanzaron gran fortuna por su carácter popular. En este sentido, cabe citar, por ejemplo, los grupos que se encuentran en la catedral de Paderborn, en Grefrath, en el Museo Diocesano de Colonia y en el castillo Real de Königsberg. Con frecuencia, eran obras consideradas como objetos mercantiles más que meros objetos de regalo o donación y, desde el punto de vista formal, se caracterizaban, salvo raras excepciones, por un estilo seco, muy esquemático, y con poca gracia y virtuosismo, aunque existían entre ellas grandes diferencias de calidad ${ }^{1}$.

Sin embargo, la escultura de la Virgen de la Peña, objeto de este estudio, coincide con una época de producción algo más tardía, hacia las primeras décadas del siglo XV, cuando podríamos admitir la existencia de un segundo grupo de imágenes de alabastro repartidas por gran parte de Europa. Eran piezas, comúnmente, de calidad muy superior, aunque más escasas que las realizadas en Inglaterra. No obstante, quizás los crecientes niveles de distribución en un amplio mercado y la producción casi en serie o repetitiva, hayan contribuido tanto a una limitada localización de las mismas como a su estudio e investigación relativamente tardíos ya que hasta el momento tan solo han sido documentadas un reducido número de obras.

Por todo ello, y debido especialmente a una incesante actividad mercantil, es muy difícil determinar los emplazamientos de las apreciadas piezas, y muchas atribuciones aún plantean numerosas interrogantes ${ }^{2}$. Esta amplia prospección de grupos de figuras y series escultóricas por toda Europa, fue posible gracias al comercio medieval de obras de alabastro que tuvo su momento más álgido entre 1430-1432. La copiosa producción fue canalizada a través de los itinerarios más importantes del comercio internacional de la época, por vía continental o marítima. Así, por ejemplo, el importante retablo compuesto por Doce figuras de santos y escenas de la Vida de la Virgen (fig. 1), entre las que destaca una Virgen entronizada con Niño, de factura y composición muy similar a la Virgen de la Peña, también asignado al "Maestro de Rímini”, recaló, incompleto, en la iglesia de Schwabstedt, en Treene, por medio de la vía fluvial que parte desde el medio Rin, pasando por el Mar del Norte hasta llegar a la desembocadura del río Eider para empalmar finalmente con el curso del río Treene hasta llegar a su destino ${ }^{3}$. Al tiempo, la febril actividad

\footnotetext{
${ }^{1}$ Véase, entre otros estudios, Evans, J.: English Art, 1307-1461. The Oxford History of English Art, 1949; Gardner, A.: English medieval Sculpture, 1951; Catálogo: English Medieval alabaster carvings. City of York Art Gallery, 1954; Stone, L.: Sculpture in Britain. The Middle Ages. The Pelican History of Art, 1955; Catálogo: Victoria Alberto Museum. English Alabasters from the Hildburg Collection. Londres, 1956.

2 A pesar de la copiosa bibliografía existente sobre el tema (véase nota 4), aún existen numerosas obras de alabastros ejecutadas en el siglo XV cuyas escuelas o autoría no están suficientemente probadas.

Deseo expresar públicamente mi profundo agradecimiento al Dr. Michael Reef, conservador del Museo Suermondt, en Aquisgrán. Me proporcionó diversos materiales científicos que fueron indispensables para la definitiva elaboración de este trabajo.

${ }^{3}$ Zubek, P.: Schloss Gottorf und Seine sammlungen. Schleswig-Holsteinisches Landesmuseum, Schleswig, 1994, pp. 149-150, figura p. 77.
} 
mercantil originó con enorme frecuencia, constantes desplazamientos de artistas cuya movilidad produjo una fecunda y recíproca influencia entre ellos, así como la fácil circulación de los modelos estéticos y las estrechas dependencias con los talleres de producción.

\section{El Maestro de Rímini y su altar: un conjunto sorprendente para una autoría enigmática}

El monumento de alabastro más importante del siglo XV es el Grupo de los Apóstoles y la Crucifixión de Frankfurt, comúnmente denominado Altar de Rímini o Retablo de la Crucifixión con apóstoles, ejecutado hacia 1430 en las tierras Bajas de Borgoña o en el medio Rin. Un excelente conjunto escultórico que constituye, sin duda alguna, la obra de enlace más importante en la producción de piezas de alabastros del siglo XV que ha sido objeto de análisis en exhaustivos estudios ${ }^{4}$.

El grupo fue realizado para la iglesia de santa María della Grazie, en Covignano, cerca de Rímini, posteriormente trasladado al Liebieghaus de Frankfurt, en $1913^{5}$ y reinstalado en 1956 en el mismo lugar ${ }^{6}$, aunque al parecer de forma arbitraria, pues la correcta disposición de los Doce apóstoles y el grupo de la Crucifixión aún constituye una gran incertidumbre7. Debido a la localización del conjunto en Italia, esta obra, al igual que aquellas derivadas de sus cualidades estéticas, ha sido aplicada a un maestro anónimo conocido bajo el genérico nombre de "Maestro de Rímini", aceptado por convección en la bibliografía especializada, lo que ha originado el reconocimiento de un singular lenguaje denominado "estilo Rímini".

La referencia a la iglesia de santa María della Grazie no fue precisada hasta las investigaciones realizadas por Mario Zuffa y Fray Tarcisio ${ }^{8}$. En general, la bibliografía relacionada con el tema ubicó este ejemplo paradigmático en el edificio de santa María Magdalena ${ }^{9}$, quizás debido a la asociación con otras noticias aparecidas en la Confraternità delli Tedeschi que menciona la

4 "El Altar de Rímini” fue considerado como la obra de imbricación más significativa a partir del estudio de Swarzenski, G.: "Deustshe alabasterplastik des 15. Jahrhunderts", en Städel-Jahrbuch, I (1921), pp. 167-213. No obstante, otras referencias importantes para el estudio tanto de este conjunto como de otras esculturas de alabastro del siglo XV son las siguientes. Kautzsch, R.: "Die Alabastergruppe der trauernden Frauen", en Jahrbuch des Schlesischen Museums für Kunstgewerbe und Altertümer, VII, 1919, pp. 176; Escherich, M.: "Eine mittelrheinische Pietà auf holländischem Boden", en Zeitschrift für christliche Kunst, 33 (1920), pp. 52; Habicht, V. C.: "Holzplastiken aus dem Kreis des Meisters des Rimini-Altares", en Kunstchronik, 34/1 (1992-23), pp. 501: Futterer, J.: "Ein Beitrag zum Werk des Riminimeisters", en Zeitscrift für bildende Kunst, 60 (1926-27), pp. 293; Katalog der Ausstellung Alte Kunst am Mittelrheim. Darmstadt, 1927, Nr. 99/100; Pinder, W.: Deutsche Plastik vom ausgehenden Mittelalter bis zum Ende der Renaissance. Postdam, 1924; Dehio, G.: Geschichte der deutschen Kunst, 1930; Witte, F.: Tausend Jahre deutscher Kunst am Rhein. Leipzig, 1932; Th. Müller: "Eine südostdeutsche Alabasterfigur vom Ende des 14. Jahrhunderts", en Phanteon 31 (1943), pp. 112; Feulner, A. y Th. Müller: Geschichte der deutschen Plastik. Munich, 1953; Wentzel, H.: "Die Marienklage aus Alabaster in Mergentheim", en Jahrbuch der Berliner Musen 2 (1960), pp. 55: Krönig, W.: "Rheinische Vespelbilder aus Leder und ihr Umkreis", en Wallraf-Richartz Jahrbuch 24 (1962), pp. 109: Von Euw, A.: "Der Kalvarienberg im Schnütgen-Museum", en Wallraf-Richartz Jahrbuch 27 (1965), pp. 118: Legner, A.: Gotische Bilderwerke aus dem Liebieghaus. Frankfurt am Main, 1966; Jopek, N.: Studien zur deustschen Alabasterplastik des 15. Jahrhunderts. Wèrnersche Verlagsgesellschaft Works, tomo 21, 1988. Otra bibliografía relacionada con este asunto, será mencionada en diversas notas posteriores.

5 Maek-Gèrad, M.: Nachanlike Grasplastiche Bildwerke, 1380-1530/40. Frankfurt-am-Main Liebieghaud, t. II, 1985, pp. 148-174.

6 Legner, A.: "Der alabasteraltar aus Rimini”, en Städel-Jahrbuch, neue folge, band 2 (1969). Herausgegeben von Ernst Holzinger und Antón Legner. Prestel Verlag, Munich, pp. 101-168.

7 Íbidem. En este trabajo, aparecen propuestas muy interesantes con relación con la probable disposición del conjunto del retablo, tomando como referencia la configuración de otro "grupo de la Crucifixión", también de alabastro, conservado en la sala del Cabildo de la catedral de Halberstadt.

8 Íbidem, p. 156, nota 24.

${ }^{9}$ Ardinari, R.: Sito Riminese. Brescia, 1616, t. I, p. 117. Cfr. Legner, p. 155, nota 23. 
iglesia de santa María della Grazie. Por otra parte, la hipotética localización de la misma obra de alabastro en otra iglesia de la Magdalena, situada por algunos historiadores en una colina cercana, carece de cualquier fundamento ya que esta segunda construcción es inexistente ${ }^{10}$.

Swarzenski11 identificó al Maestro del altar de Rímini, o "Maestro de Rímini”, con el Maestro Gusmin, escultor de Colonia activo en Italia que Ghiberti había loado en sus Commentari12; identificación que no ha sido aceptada posteriormente en la bibliografía especializada ${ }^{13}$. Las tesis de la procedencia renana-alemana del "Maestro de Rímini" fue compartida por muchos historiadores ${ }^{14}$, aún después de que Richard Krautheimer ${ }^{15}$ desvinculara al autor del retablo con el Maestro Gusmin y de que Walter Paatz, con base a los estudios de Werner Körte ${ }^{16}$ y Schönberger ${ }^{17}$, entre otros, hubiera aportado cada vez más indicios de que las obras de alabastros provenían de un área comprendida entre el norte de Francia y los Países Bajos meridionales, en los talleres de Lille, Arras y Tournai ${ }^{18}$.

Así pues, las investigaciones efectuadas hasta el momento sitúan el origen del "Maestro de Rímini", bien en el medio Rin o en un área comprendida entre el norte de Francia y el sur de los Países Bajos; su concreta procedencia como la definitiva localización de sus talleres sigue, aún, siendo un misterio. Sin embargo, cada vez más existen sólidos argumentos científicos para situarlo en la zona fronteriza entre Francia y los antiguos Países Bajos meridionales, en el triángulo compuesto por las ciudades de Lille, Arras y Tournai ${ }^{19}$. También se ha planteado la posibilidad de que el centro de producción esté situado en el norte de Francia, pero esta hipótesis no ha sido aprobada ya que está basada en una incorrecta interpretación de los textos relativos a las actividades de los talleres del duque de Borgoña ${ }^{20}$.

En general, pues, se admite que el origen de este arte podría encontrase en los antiguos Países Bajos meridionales, por el hecho de la igualdad de estilo con el arte de estas regiones durante la primera mitad del siglo XV. Además, esas conexiones "flamencas" son corroboradas por las estrechas relaciones existentes entre estas esculturas de alabastros y las resoluciones pictóricas de Jan van Eyck, Roger van der Weyden, Maestro de Flèmalle y Robert Campin ${ }^{21}$.

\footnotetext{
10 Legner, A.: art. cit., pp. 101-168.

11 Swarzenski, G.: "Deustshe alabasterplastik des 15. Jahrhunderts" art. cit., pp. 167-213.

12 Swarzenski, G.: "Der Kölner Meister bei Ghiberti”, en Vorträge der Bibliothek Warburg, Vörtrage 1926-27. Leipzig-Berlin, 1930, pp. 1-22.

13 Especialmente a partir del trabajo de Krautheimer, R.: "Ghiberti and Master Gusmin", en The Art Bulletin, XXIX (1947), pp. 25-35; Krautheimer, R.: Lorenzo Ghiberti. Pricenton Monographs in Art and Archeology, Pricenton, 1982, pp. $62-67$ y pp. $353-357$.

14 Entre ellos, Weigert, H.: Europäsche Plastik der Spätgotik und Renaissance. Frankfurt am Main, 1963, p. 19; y Decker, H.: Gotik in Italien. Viena y Munich, 1964, p. 37.

15 Krautheimer, R.: "Ghiberti and Master Gusmin"... art. cit., pp. 25-35.

16 Körte, W.: "Deustsche Vesperbilder in Italien", en Kunstgeschitliches Jahrbuch der Bibliotheca Herztiana I (1937), pp. 41.

17 Schönberger, G.: “Alabasterplastik”, en Reallexikon zur deutschen Kunstgeschichte, t. I, 1937, pp. 302 y ss.

18 Paatz, W.: "Stammbaum der gotischen Alabasterskulptur 1316-1442", en Kunstgeschichtliche Studien für Hans Kauffmann. Berlin, 1956, pp. 130; Paatz, W.: "Prolegomena zu einer Geschite der spätgotischen Skulptur im 15. Jahrhundert". Abhandlungen der Heidelberger Akademic der Wissenschaften, 1956; Paatz, W.: Süddeutsche Schnitzaltäre der Spätgotik. Heidelberg Kunstgeschichtliche Abhandlungen, Heidelberg, 1963.

${ }^{19}$ En este sentido se ha pronunciado Walter Paatz. Véase al respecto las publicaciones citadas en las notas 18 y 45. La investigación actual sobre este tema, aprueba, en general, esta teoría.

20 AA. VV. (Aniick Notter, recopilación de textos): "La sculpture de gothique tardif en Artois (1430-1530), en Fragments d`une Splendeur. Arras à la fin du Moyen Age. Museè des Beaux-Arts d’Arras, 2000, p. 111 y pp. 125-129.

${ }^{21}$ Baun, I.: "Vesperbild aus dem Kreise Rogiers van der Weyden", en Pantheon, dècembre (1929), pp. 563-569; Duverger, J.: "Brugge Schilders ten tijde van Jan van Eyck", en Miscellanea Edwin Panofsky. Bulletin Musèes Royaux des Beaux-Arts, 1955; Paatz, W.: "Stammbaum der gotischen Alabasterskulptur 1316-1442... art. cit.,; Panofsky, E.: Early Netherlands Painting: Cambridge, 1958; Catálogo: Masterpieces of Flemish Art: Van Eyck to Bosch. The Detroit
} 
Por otra parte, ha sido estudiada la influencia de la Europa Central, y más particularmente de la ciudad de Praga, en la escultura del "Maestro de Rímini" y de su entorno22. En este sentido, obras bellísimas como la sedente Virgen con Niño del Museo del Louvre, adquirida en Venecia, o la imagen de igual iconografía perteneciente al Museo Victoria y Alberto, en Londres, proveniente de la iglesia de san Francisco, en Rávena, así como la Virgen de Porto, en Legnano (Lombardía), todas ellas documentadas como obras del "Maestro de Rímini", están notoriamente influidas por las características de Bohemia 23 .

Como antes se indicaba, todo ello fomentó la génesis y el desarrollo del denominado "estilo Rímini" que responde a constantes formales muy concretas. Estas cualidades estéticas, comunes prácticamente a todas las obras del enigmático autor, están basadas en las miradas de los personajes extraviadas en sus propios sentimientos; en el carácter repetitivo de una fórmula convencional; en la adecuada solución de los cuidados drapeados cuyas colgaduras caen libremente; en los cabellos sucintamente tallados; en los rasgos faciales angulares; y en el volumétrico drapeado, cuyos profundos pliegues tubulares en forma de "V, en los ejes centrales de las composiciones, forman un juego lírico de tejidos y telas capaz de ocultar las formas físicas de los personajes. Un efecto en su conjunto de una elegante restricción que promueve sentimientos intensos o sutiles, pero siempre controlados de manera serena.

No obstante, el singular "estilo Rímini", sobresale, especialmente, por la concreción de una de sus variantes lingüísticas denominada "estilo suave" o "bello estilo", iniciado hacia 1400, aproximadamente, coincidiendo con algunas décadas después de la eclosión del Gótico Internacional, y extendido hasta 1440, observándose, en su desarrollo, algunos matices o variantes formales escasamente diferenciales. Es un concepto aplicado a las excelentes calidades de las bellas madonnas de alabastro caracterizadas por la grácil postura curvada en forma de "S" y los singulares drapeados que envuelven las formas anatómicas por medio de tubos y pliegues en forma de "V", como ocurre con el temprano y arquetipo ejemplo, ejecutado hacia 1390, de la Virgen con Niño de Krumau, en Praga, hoy conservado en el Kunst Historiches Museum de Viena. Precisamente fue en Europa Central, en Bohemia, hacia el final de la primera década del siglo XV, cuando estos pliegues voluminosos y barriendo el suelo se transformaron en pliegues más numerosos y densamente distribuidos, muy tallados y ejecutados con una precisión rítmica, como fueron adaptados a la figura de Juan Evangelista de la iglesia de Tyn, en Praga $^{24}$, y en la expresión más refinada, aunque excesivamente icónica, de los personajes que decoran la fachada de Ulm Munster, ejecutados por el Maestro Hartmann hacia $1420^{25}$.

Por otro lado, el "estilo suave" de las figuras de alabastros del siglo XV muestra estrechas relaciones artísticas con el peculiar lenguaje de Claus Sluter (fallecido en 1406), originado así interesantes vínculos con retablos neerlandeses de madera tallada de períodos anteriores. También parece

Institut of Arts, 1960; Legner, A.: "Der alabasteraltar aus Rimini... art. cit., pp. 101-168; Maek-Gèrad, M.: Nachanlike Grasplastiche Bildwerke, 1380-1530/40... ob.cit.

22 Kutal, A.: "Le problème des Pietà horizontales", en Umèni, XI (1963), pp. 321 y ss.; Kutal, A.: "Les problèmes limitrophes de la sculpture Tchèque au tornant 1400", en Sbornik Praci Filosofickè Brnêsnkè University, 18 ed. F:13 (1965), Brno, pp. 5-23.

${ }^{23}$ Suduirant, G. de: Nouvelles acquistions du department des Sculptures, 1992-1995. Paris, 1996, p. 34; Blanc, M.: Retables. La Colllection du Musèe des Arts Dècoratifs. Rèunion des Musèes Nationaux, 1998. En las páginas 117-118, Nr. 43, en las que analiza la escultura "Virgen de Piedad", demuestra la influencia de Praga, con base a los estudios de Kutal. Además, menciona otras obras donde se aprecia ciertas reminiscencias al arte de Bohemia, como las "Piedades" existentes en la catedral de saint-Guy, en Praga y la perteneciente a la iglesia de saint-Ignace de Jihlava.

${ }^{24}$ Kutal, A.: "Les problèmes limitrophes de la sculpture Tchèque au tornant 1400... art. cit., pp. 5-23.

25 Husband, T.B.: "Tilman Riemenschneider and the tradition of alabaster carving", en Simposium Tilman Riemenschneider: A late Medieval Master Sculptor”, 3-4 december (1999), Washington. Pricenton. Editorial Associates, Yale University Press, New Haven y Londres, 2004, pp. 65-81. 
existir en las primeras décadas de la misma centuria, estrechas concomitancias entre el "estilo suave" de las tallas de alabastros con la escultura neerlandesa de piedra y de madera.

Del "estilo suave" o "bello estilo", propio de numerosas imágenes de alabastros de vírgenes sedentes con niño, se transita luego hacia una reducción de estas maneras delicadas para llegar a un estilo determinado por un progresivo endurecimiento de las formas.

Las primeras obras relacionadas con el Altar de Rímini ${ }^{26}$ son ejecuciones repetitivas destinadas hacia un gran mercado de exportación que alcanzó un gran apogeo durante el segundo cuarto del siglo XV. Entre ellas habría que citar, por sus analogías formales e identidad estilística, las siguientes piezas: san Pedro, en el Museo Boijmans van Beuningen, en Roterdam; san Andrés, san Bartolomé y otros dos santos aún no identificados, en Saint-Omer ${ }^{27}$; una figura de mujer sin cabeza, probablemente una María de luto, perteneciente al Metropolitan Museo, en Nueva York ${ }^{28}$; san Juan Bautista, anterior al grupo de Frankfurt ${ }^{29}$, en el mismo museo neoyorkino ${ }^{30}$. Un Apóstol de la misma serie, ha sido adquirido por el Skulpturensammlung, en Berlín ${ }^{31}$.

Y en cuanto a la tipología exclusiva del conjunto de la Crucifixión del altar de Rímini, los siguientes ejemplos manifiestan evidentes vínculos iconográficos: el Calvario de alabastro, en la catedral de Halberstadt; las Mujeres de luto, en Wroclaw; y la obra más tardía, hacia 1470, Virgen en luto que forma conjunto con una de las Marías y san Juan, obra probable de un escultor de Estrasburgo, en el entorno del artista Nicholas Gerhaert, nacido en Leyden. Todas ellas, al igual que la Crucifixión del altar de Rímini, están relacionadas con diversas composiciones pictóricas, especialmente con el Tríptico del Descenso de la Cruz de Robert Campin.

\section{Talleres, centros de producción y cualidades del singular "estilo Rímini"}

Debido a la estructura homogénea del alabastro y a los escasos resultados producidos por las investigaciones y análisis de su composición química, aún no se han localizado tanto los yacimientos antiguos como el origen concreto de un grupo de obras pertenecientes a las primeras décadas del siglo XV, como sucede con el paradigmático ejemplo del Altar de Rímini. Además, no se puede partir de la base de que los talleres se hayan encontrado en las cercanías inmediatas de los yacimientos, debido a la gran actividad comercial de esta materia prima o a la exportación de obras ya acabadas. Por tanto, tienen escasa probidad aquellas hipótesis que tienden a relacionar la ubicación del yacimiento con el taller, tal como realmente existía en Inglaterra alrededor de los ricos yacimientos de Derbyshire.

A pesar de las últimas investigaciones sobre el tema, los historiadores del arte plantean diversas alternativas en lo que se refiere a la localización de los talleres de origen ya que abarcaban una amplia área de expansión que incluía desde el medio Rin a una zona comprendida entre el norte de Francia y los antiguos Países Bajos meridionales, en un hipotético triángulo geográfico compuesto por las ciudades de Lille, Arras y Tournai. Aunque cada vez cobra mayor rigor científico la recientes investigaciones que sitúan la producción de obras de alabastro del siglo XV en el área artístico-geográfico del

\footnotetext{
26 Fueron estudiadas especialmente por Swarzenski, G.: "Deustshe alabasterplastik des 15. Jahrhunderts... art. cit., pp. 167-213. Véase, además, las referencias bibliográficas de este ejemplo paradigmático mencionadas en la nota 4.

27 Catálogo: Exposición Ghent 1994, pp. 327-329, Nr. A-D-. Steyaert, en su contribución en el mismo estudio, atribuye a estas figuras a los talleres de Turingia, asignándoles una cronología que oscila entre 1425 y 1430.

28 Catálogo: Exposición Nueva York, 1999b, Nr. 216, p. 177.

29 Considerado así por Husband, T.B.: "Tilman Riemenschneider and the tradition of alabaster carving", en Simposium Tilman Riemenschneider: A late Medieval Master Sculptor”, 3-4 december (1999), Washington. Pricenton. Editorial Associates, Yale University Press, New Haven y Londres, 2004, p. 72.

30 Íbidem, 72, figura 12; Catálogo: Exposición Nueva York 1999b, Nr. 215, p. 177.

31 Un apóstol, tal vez de la misma serie, ha sido adquirido por el Skulpturensammlung de Berlín. Véase, Krohm, 2002, pp. 54-56, figura 1.
} 
sur de los antiguos Países Bajos. Y, más concretamente, con los talleres de Tournai, en las tierras bajas del sur, pues su densidad de producción y las condiciones estilísticas e históricas son más análogas con el Altar de Rímini ${ }^{32}$. De cualquier modo, en aquel amplio espacio se encontraban gremios de artistas que trabajaban en talleres de exportación en los que se fabricaron distintas calidades de esculturas, desde la obra de arte más exigente hasta el objeto de devoción más ingenuo.

La concreta localización de los centros de producción sigue aún sin resolverse. Las esculturas más conocidas y estudiadas se ubican en Italia y en el centro de Europa. También existen obras preciosas en Francia, como el Ángel de la Anunciación, en Douai, el Grupo de la Natividad, en el Museo de Artes Decorativas, en París ${ }^{33}$, la Virgen de la Anunciación, en Clerques o la Virgen del Calvario, en el Museo Chalons-sur-Saone ${ }^{34}$. Otras esculturas hermosísimas son la Piedad, en el Museo Alberto y Victoria, en Londres, y la obra menos conocida de las Mujeres dolorosas con el desmayo de la Virgen, en el Museo del Cau Ferrat, en Sitges (Barcelona). No obstante, la mayoría de los estudiosos del tema asienten que el "estilo Rímini" proviene de Flandes, aunque otros opinan que los talleres franceses de Lille o Arras adquirieron un mayor protagonismo. Como se ha dicho con relación a obras muy concretas ${ }^{35}$, los análisis lingüísticos pueden dilucidar las posibles diferencias entre escuelas de alabastros parisienses o neerlandesas. Pero todo esto es muy complejo, pues una obra determinada pudo haber sido creada en un taller de alabastro de París por un maestro neerlandés, o bien en un taller neerlandés por un maestro procedente de París o formado en esta ciudad. Lo que parece mucho más probable es que ambos lenguajes, el francés y el neerlandés, se hubiesen fusionado pues hubo una estrecha conexión entre los talleres, bien existentes en la misma ciudad o incluso geográficamente distantes, además de una gran movilidad de los artistas debido a la vitalidad del comercio internacional lo que se tradujo en afinidades y similitudes estilísticas en diversas composiciones escultóricas.

No parece existir la menor duda de la existencia de talleres cualificados en piezas de alabastro, pues en la primera mitad del siglo XV se tiende hacia la especialidad de talleres en función de los usos específicos de cada material. Pero el trabajo y manipulación del alabastro exigía una gran destreza debido a su propia naturaleza. E incluso parece que fue probable la existencia de talleres especializados en la producción de obras de exportación y en piezas destinadas para la Corte. De esta manera, por ejemplo, se tiene noticia que los duques de Borgoña fundaron un taller para escultores de alabastro en Lille que se abastecía de los yacimientos existentes en Borgoña y el Jura borgoñés, cerca de Salins ${ }^{36}$. Sin embargo, las obras de exportación tenían una calidad desigual,

\footnotetext{
32 Sobre la producción de diversas manifestaciones artísticas y el influjo de los talleres de Tournai, consultar Soil de Moriamè, M. E-J: Les anciennes industries d'art Tournaisiennes à l'exposition de 1911. Tournai, 1912; G. Ring, G.: "Beiträge zur Plastik von Tournai im 15. Jharhundert", en Belgische Kunstdenkmäler, núm. 1 (1923), Munich, pp. 269 y ss.; Rolland, P.: "La double ècole de Tournai, pinture et sculpture", en Mèlanges Hulin de Loo, Bruselas, 1931, pp. 296 y ss. En referencia a los ornamentos en piedra de Tournai en forma de epitafios y sus influencias sobre el arte de la época, véase Rolland, P.: "Stèles funèraires Tournaisiennes gothiques", en Revue Belge d'Archèlogie et d'Histoire de l'Art, núm. 20 (1951), pp. 189 y ss.

33 Véase, Blanc, M.: Retables. La Colllection du Musèe des Arts Dècoratifs. Rèunion des Musèes Nationaux, 1998, Nr. 44.

${ }^{34}$ Con relación a las obras localizadas en Francia, véanse, entre otras, las siguientes publicaciones. Blanc, M.: Retables...; AA. VV.: Les Princes des fleurs de lis. La France et les Arts en 1400. Rèunion des Musèes Nationaux, París, 2004; Catálogo de Exposición: Paris 1400. Les arts sous Charles VI. Musèe du Louvre, 22 de marzo - 12 de julio, 2004. Réunion des Musèes Nationaux, Paris, 2004.

35 Legner, A.: "Der alabasteraltar aus Rimini... art. cit. El autor, para constatar este fenómeno y vincularlo a otros exponentes, hace referencia al extraordinario grupo de las Mujeres Dolorosas de Breslau, en el Museo Nacional de Warschau, p. 126.

36 Keller, H.: "Italien und die Welt der höfischen Gotik", en Sitzungsberichte der Wissenschaftlichen Gesellschaft an der Johann Wolfgang Goethe. Universität Frankfurt/Main, 1964. Wiesbaden, 1967. En este trabajo se insiste en el carácter cortesano del arte del alabastro al tiempo que se expresa la preferencia de este noble material, antes que el empleo del mármol, en los pleurants de los sarcófagos de Dijon y en la serie de estatuas del siglo XIV de Colonia.
} 
aunque fueron, en general, siempre superiores a las que en el siglo anterior habían sido elaboradas en los talleres ingleses. Además, en algunos casos, la cercanía de algún taller de la Corte sirvió de ejemplo directo para las mejores obras de los talleres de exportación. Y aún más, en estos talleres especializados se cultivaba también un tipo iconográfico determinado, tanto en los talleres centrales de alto rango -aquellos destinados para abastecer a la Corte- como en el taller del maestro de las figuras de Rímini, e igualmente en los talleres más tardíos del siglo XV existentes en los Países Bajos y Alemania ${ }^{37}$.

Esta producción estuvo sometida a variantes lingüísticas en el ámbito del mismo estilo. De esta manera, las obras de las primeras décadas del siglo XV, entre 1400 y 1420, aproximadamente, se caracterizan por una denotada belleza formal y la denominada "elegancia distanciada". Un estilo armonioso que traducía la elegancia cortesana en contraste con el lado crudo de la vida; es decir, mientras que en la corte de Borgoña se cazaba, jugaba y hacían el amor, el resto de los mortales trabajaba. Todo ello, lógicamente, debido a la existencia de una sociedad bipolar: de un lado, el orden natural permitió a las clases altas practicar las actividades de placer; mientras que en el otro, las clases inferiores estaban destinadas a una vida dedicada absolutamente al trabajo para satisfacer las necesidades de unos pocos privilegiados ${ }^{38}$. Así, por ejemplo, se retrata dicha realidad en la conocida miniatura sobre pergamino realizada por los hermanos Limbourg Los calendarios de las Tres Ricas Horas del duque de Berry (ca. 1415), en la que los campesinos son representados en sus duras faenas agrícolas, concebidos de este modo por el influyente duque como parte integral del mundo.

Sin embargo, hacia 1440 las composiciones muestran una gran solemnidad y vehemencia, como podemos apreciar en el grupo de alabastro del Museo Schnütgen, en Colonia, y el magnífico conjunto del Llanto sobre Cristo muerto, en el Museo del Ermitage, en San Petesburgo. Después de mediados del siglo XV se manifiesta el lado oscuro del realismo del gótico alemán, como el agónico estertor del Gótico Internacional, en imágenes que expresan la fogosidad de las clases inferiores, como figuran traducidas en las expresiones de los rostros de la magnífica Pasión, en Karlsruhe ${ }^{39}$. Cambios o matices diferenciales de estilo que estaban supeditados a las influencias ejercidas por otras artes plásticas, especialmente los modelos pictóricos ${ }^{40}$.

En lo que hace referencia a la iconografía mariológica, las esculturas de alabastro del siglo XV suponen una adecuada respuesta de aquellas delicadas vírgenes propias de la pintura en toda su diversidad tipológica De esta manera, la posición, los gestos anímicos, la introversión espiritual y la resolución formal de los drapeados, parecen inspirarse en las representaciones de Jan van Eyck, Roger van der Weyden, el Maestro de Flèmalle y Robert Campin. Estas características, entre otras, fueron apreciadas por el taller del "Maestro de Rímini" y su ámbito de expansión. Es decir, hubo en las obras de estos maestros y en las esculturas de alabastros del siglo XV, en las que

\footnotetext{
${ }^{37}$ Legner, A.: "Der alabasteraltar aus Rimini... art. cit., p. 168.

38 Pinder, W.: Deutsche Plastik vom ausgehenden Mittelalter bis zum Ende der Renaissance. Postdam, 1952, p. 169 y p. 255.

39 Para un completo debate sobre el tema véase, Catálogo: Frankfurt 1975, pp. 19-26.

40 El fenómeno de la confluencia entre pintura y escultura, ha sido tradicionalmente analizado por acreditados investigadores belgas. Véase, entre otros, además de las citas indicadas en la nota 21, los siguientes estudios. Rolland, P.: "Un sculpture encore existante polychromèe por Robert Campin”, en Revue belge d'Archèologie et d'Histoire de l'Art, II (1932), pp. 335 y ss.; Maeterlinck, L.: Roger van der Weyden et les Ymagiers de Tournai. Extracto del tomo LX de Mèmoires publicado por la "Acadèmie Royale de Belgique", 1900; Maeterlinck, L..: "Roger van der Weyden, sculpteur", en Gazette de Beaux-Arts, núm. 26 (1901), 265 pp.; Destrèe, J.: "A propos de linfluence de Roger van der Weyden (Roger de la Pasture) sur la sculpture brabançonne”, en Annales de la Sociètè Royale d'Archèologie de Bruxelles, 1914-19, s.p; Guiette, L.: L'influence de Roger van der Weyden sur la sculpture brabançonne au XVe. Siécle. Etude stylistique. Estudio manuscrito para la obtención de Licenciado en Historia del Arte y Arqueología. Universidad de Lovaina, 1960; Th. Müller: Sculpture in the Netherlands, Germany, France and Spain 1400 to 1500. The Pelican History of Art, 1966.
} 
influyeron de manera decisiva, una cierta reminiscencia a la tradición del arte gótico ${ }^{41}$. Por otro lado, al compararse las relaciones estilísticas existentes entre las esculturas de alabastro y las obras pictóricas de Jan van Eyck, Rogier van der Weyden y, singularmente, las producidas en el entorno del Maestro de Flèmalle, se ha constatado la distribución de numerosas obras de alabastros del siglo XV en la región franco-neerlandesa ${ }^{42}$.

Aunque, en realidad, estas comparaciones no solo deben emitirse con base a determinadas ejecuciones compositivas y aspectos fisiológicos, sino más bien a equivalencias más profundas entre todas las artes plásticas y representativas del momento histórico. Y todo ello, en el marco de la tradición del estilo Gótico Internacional que, aunque ya no tan moderno por estas fechas, aún es una corriente de gran difusión popular debido al influjo de su lenguaje artístico ${ }^{43}$.

Las referencias a los "maestros flamencos" constituyen también algunas claves de interpretación formal de la Virgen de la Peña. De este modo, parece evidente que el ritmo de la composición, la agitación de los pliegues y la terneza de su rostro dependen de las soluciones de Roger van der Weyden; el hecho de que en la pintura de Van der Weyden el retrato desempeñe un papel tan importante, en general en las esculturas de alabastro del siglo XV, parece una consecuencia lógica de las repercusiones del arte de Tournai, su tierra natal, y los talleres correspondientes. Por otro lado, el rostro de la Virgen de la Peña parece extraído del pincel de Robert Campin, en el que su genuino contraste de luces y sombras determina el modelado escultural del conjunto.

La mayoría de estas obras adscritas al "Maestro de Rímini" son de escasas dimensiones, apenas superan los treinta centímetros. La Virgen de la Peña mide algo menos. Sin embargo, es necesario precisar que los talleres de alabastro fabricaron esculturas de diferentes proporciones, no de muchas, aunque proliferaban las de pequeño formato. Al ser tan chicas, las figuras podían ser colocadas fácilmente en cualquier lugar y eran ajenas a las posibles disposiciones o consejos emanados desde los talleres relativos a su ubicación. Es decir, estas pequeñas esculturas no participaron de aquella homogeneidad absoluta que existió en la adecuada conjunción de los retablos de la Edad Media en los que se recreaba un amplio mundo imaginario.

Los reducidos tamaños de las tallas de alabastro facilitaban, por otro lado, su exportación hacia distintos mercados. En general eran colocadas en cajas de madera para su fácil traslado, y así se explica que los reversos de gran parte de estas esculturas fuesen de base hueca al objeto de adaptarlas y asegurarlas en estos embalajes de viajes, como sucede, de igual manera, con la Virgen de la Peña.

De los pequeños formatos de las esculturas de alabastro destinadas para su exportación, podemos inferir que no estaban concebidas para ser expuestas al público en general, en espacios amplios y holgados, sino más bien fueron ideadas para la veneración particular. Y, en este sentido, podríamos admitir que la Virgen de la Peña fue concebida como una obra de devoción, un tradicional objeto de rogativas.

Las menudas proporciones de las esculturas posibilitaron su amplia distribución y una ejecución repetitiva en cuanto a las fórmulas. Constituían convenciones formales frecuentes que obedecían a tradiciones visuales estereotipadas y al influjo de ideologías y estados de opinión que permanecieron, al menos, hasta comienzos del siglo XVI. Todo ello fue capaz de acomodarse a un

\footnotetext{
${ }^{41}$ Las confluencias entre pintura y escultura son más reconocibles a medida que vayamos examinando más obras. En este sentido, aún subsisten analogías entre la pintura de los viejos maestros y esculturas tardías. Sirva, como ejemplo, el "Grupo del Entierro de Cristo" (c. 1440), en el Museo del Ermitage, de San Pestesburgo, con el "Tríptico de la Pasión de Cristo" de Roger van der Weyden, en el Kunsthistorisches Museum de Viena; en ambas composiciones las figuras de las Marías mantienen semejanzas extraordinarias.

42 Legner, A.: "Der alabasteraltar aus Rimini... art. cit., pp. 101-168.

43 Véase, Catálogo: The international style. The arts en Europe around 1400. Baltimore, 1962.
} 
singular y duradero lenguaje estilístico nacido de las influencias neerlandesas y del Rin que abasteció una corriente artística medieval hasta los albores del humanismo renacentista de tardía recepción, como sabemos, en la Europa nórdica.

Eran pues composiciones muy populares de gran devoción cuyas facturas eran continuamente reiteradas, tanto por maestros como por sus seguidores o discípulos. De esta manera, aceptaríamos la existencia de repeticiones temáticas con base a trasuntos iconográficos precisos: las excelentes esculturas localizadas en Isola Bella ${ }^{44}$, ángeles ${ }^{45}$ y el Grupo de mujeres del Calvario del Museo Schnütgen ${ }^{46}$. Pero hubo una predilección por los amplios Grupos de Crucifixión que arraigó desde épocas tempranas hasta el orto iconoclasta. También la representación de los Apóstoles ocupó un privilegiado tratamiento; ambos temas ocupan el escenario del Altar de Rímini, punto de partida, como hemos visto, para el estudio de las obras de alabastro del siglo XV. Pero el culto mariológico había conocido un desarrollo considerable desde el siglo XII, y la representación de la Virgen evolucionó en sus formas y lenguajes. De esta manera, el tipo iconográfico de la Virgen de la Anunciación, proveniente de los Países Bajos, tuvo una gran influencia. En este caso, nos encontramos con una tradición continua en el tratamiento de este tema que se remonta al Retablo de la Pasión, en Dijon, realizado por Jacques de Baerze, cuyos registros se perpetuaron de manera notable en los retablos brabanzones del siglo XV: entre los ejemplos que se podrían relacionar con esta obra, se encuentran el Retablo de Marienkirsche, en Gdansk, de origen anverino, y el Retablo de Clausen, cerca de Treves, ambos de análoga composición ${ }^{47}$.

Otro trasunto iconográfico de origen nórdico, aunque de mayor carga dolorosa, fue la Piedad entronizada o Virgen que sostiene entre sus rodillas al agonizante cuerpo de Jesús. Nació en los conventos del valle del Rin, donde fue denominado Vesperbilder (hora de vísperas), que corresponde al episodio evangélico del Descenso de la Cruz: uno de los ejemplares más antiguos es el existente en el Landesmuseum Rhheinisches, en Bonn, realizado hacia 1300 en madera policromada ${ }^{48}$.

Pero no hay que olvidar que el tema de la "Piedad" deriva de la Virgen tradicional llevando a su Niño sobre las rodillas, cuya formulación fue articulada por medio de la rigidez y severidad de las Sedes Sapientae hasta las gráciles y dinámicas maneras más tardías del Gótico Internacional, entre las que se encuentran la Virgen de la Peña que podría constituir una pieza integrante de una serie estilística conformada por otras esculturas, también ejecutadas por los talleres del "Maestro de Rímini". De esta manera, similares características podemos encontrar en una sedente Virgen con Niño (fig. 2), tallada en alabastro hacia 1420 en la escuela del medio Rin, que forma parte de un conjunto de escenas integradas en un relicario de madera de roble, en la iglesia de Schwabstedt, en Treene ${ }^{49}$, y en otra escultura de igual iconografía,

\footnotetext{
44 Legner, A.: "Der alabasteraltar aus Rimini... art. cit., p.168, nota 206.

45 Swarzenski, G.: "Deustshe alabasterplastik des 15. Jahrhunderts,", en Städel-Jahrbuch, no. 1 (1921), pp. 167-213; Paatz, W.: "Stammbaum der gotischen Alabasterskulptur 1316-1442", en Kunstgeschichtliche Studien für Hans Kauffmann. Berlin, 1956; Paatz, W.: "Prolegomena zu einer Geschite der spätgotischen Skulptur im 15. Jahrhundert". Abhandlungen der Heidelberger Akademic der Wissenschaften, 1956, Ausstellungskatalog Frankfurter Skulpturen im Historischen Museum Frankfurt am Main. Frankfurt am Main, 1959, Nr. 17.

${ }^{46}$ En la actualidad en una colección privada de Suiza. Véase, Legner, A.: "Der alabasteraltar aus Rimini... art. cit., pp. 101-168.

47 Vésae, Debussche, 1994 y Steyaert, 1994.

48 Baun, J.: "Verperbild aus dem Kreise Rogiers an der Weyden", en Phanteón, núm. 4 (1929), pp. 563-569; Ziegler, J.E.: Sculpture of Compassion: The Pietà and the beguines in the southern low countries c.1300-c-1600. Institut Historique Belge de Rome. Bruselas, Roma, 1992.

49 N. inv. 1931/197. "Virgen con Niño", alabastro con restos de policromía y sobredorado. Altura: en torno a $25 \mathrm{~cm}$. Bibliografía: Haupt, R.: 1887, I, p. 508; Sawarzenski, G.: "Deustshe alabasterplastik des 15. Jahrhunderts", en StädelJahrbuch, I (1921), Nr. 185, pp. 167-213; Haupt, R.: "Über Arbeiten in Alabaster namentlich mittelalterliche", en Festschrift... des Kunstgewerbemuseums. Flensburg, 1928, Nr. 79; Johnsen, W.: "Die Verkündigungsgruppe des Schwabstedter
} 
también de alabastro, aunque algo más tardía, datada hacia 1430, localizada en la colección londinense Sotheby`s (fig. 3) 50 .

Las espléndidas investigaciones de estas obras, ampliaron el conocimiento sobre las esculturas de alabastros producidas en el siglo $\mathrm{XV}$, tanto en su magnitud como en su diversidad temática. A través de estos trabajos se dieron a conocer obras recién descubiertas o escasamente conocidas, y otras fueron ampliamente estudiadas. Así pues con la localización definitiva de un grupo de obras que en la actualidad se encuentran muy repartidas por toda Europa, se había creado un punto de partida para la investigación de esculturas de alabastro del siglo XV. Y, ahora, la señera escultura de la Virgen de la Peña ocupa un eslabón más de aquella larga cadena de imágenes de alabastro de notabilísima calidad que fueron distribuidas hacia los confines del mundo, recalando en Betancuria, en una de las poblaciones más hermosas del profundo e insondable Atlántico.

\section{La Virgen de la Peña, una obra europea de los talleres de Rímini}

Constituye una de las esculturas más antiguas de Canarias ${ }^{51}$, y la más remota de las siete patronas existentes en el Archipiélago. En este sentido, aunque su imagen data de las primeras décadas del siglo XV es, desde mediados de la centuria siguiente, aproximadamente, "abogada y defensora" de Fuerteventura, en detrimento de la escultura de Nuestra Señora de la Concepción, custodiada en el retablo principal de la iglesia matriz de Betancuria, antigua catedral del Archipiélago.

La fuerte carga fervorosa de la Virgen de la Peña está relacionada con su legendaria aparición, en el barranco de Malpaso, en la Vega de Río Palmas, un abrupto y rocoso acantilado de deslumbrante belleza. Es como si el carácter misterioso y encubierto de estos recónditos parajes de duras peñas y nacientes de aguas, estuviese relacionado con el sentido de lo oculto, propio de muchas vírgenes homónimas distribuidas por gran parte de geografía europea.

A su indudable protagonismo histórico, social y religioso, se añade unas excelentes cualidades relacionadas con el "estilo Rímini", lo que proclama, una vez más, la apertura y conexiones del Archipiélago con Europa desde fechas muy tempranas.

Una encantadora escultura de alabastro tiernamente tallada y de delicada belleza que por las texturas de su material aumenta su carga de trascendencia y emotividad, producto de un taller de exportación activo desde las primeras décadas del siglo XV, quizás entre 1400 y 1440, bien en el medio Rin o en una zona fronteriza entre el norte de Francia y los Países Bajos meridionales, en las ciudades de Lille, Arras y Tournai. Sobre la base de criterios formales se puede reconocer como obra del denominado "Maestro de Rímini", o de su entorno, cuya ominosa existencia -como ha sido desarrollado en las páginas anteriores- se debe a la asunción de su nombre por convección.

El grupo está formado por la imagen sedente de la Virgen y la talla erguida del Niño a su derecha, todo ello en un logrado equilibrio compositivo que proporciona una solidez estructural del conjunto en consonancia con los ejemplos más notables de la escultura gótica (fig. 4). No obstante, el ritmo orgánico que une al grupo posee cualidades distintivas: cada figura con su propia

\footnotetext{
Alabasteraltars", en Die Hiemat, 1935; Schönberger, G.: "Alabasterplastik", en Reallexikon zur deutschen Kunstgeschichte, I, 1937, p. 302; Scheffler; W.: 1938, p. 16; Spielmann, H. (editor). Texto redactado por Zubek, P.: Schloss Gottorf und Seine Sammlungen. Schleswig, 1994, pp. 149-150, Nr. 87, figura 87.

50 Sotheby`s Sale 7965. Jan 22, 2004. Lot. N. 159. Altura: $18,95 \mathrm{~cm}$.

51 Durante la evangelización del Archipiélago en las últimas décadas del siglo XIV, con el establecimiento de catalanes y mallorquines y la erección del primer Obispado, es muy probable que hubiesen llegado imágenes religiosas, algunas traídas por los misioneros franciscanos. No obstante, en la actualidad no está documentalmente probada la existencia de estas esculturas. Por otro lado, en la iglesia de san Juan Bautista, en Puntallana, en la isla de La Palma (Canarias), existe una pieza de alabastro muy deteriorada y fragmentada que representa a la "Virgen con el Niño"; es de procedencia europea, quizás del siglo XV, aunque no fue inventariada en su parroquia hasta 1556.
} 


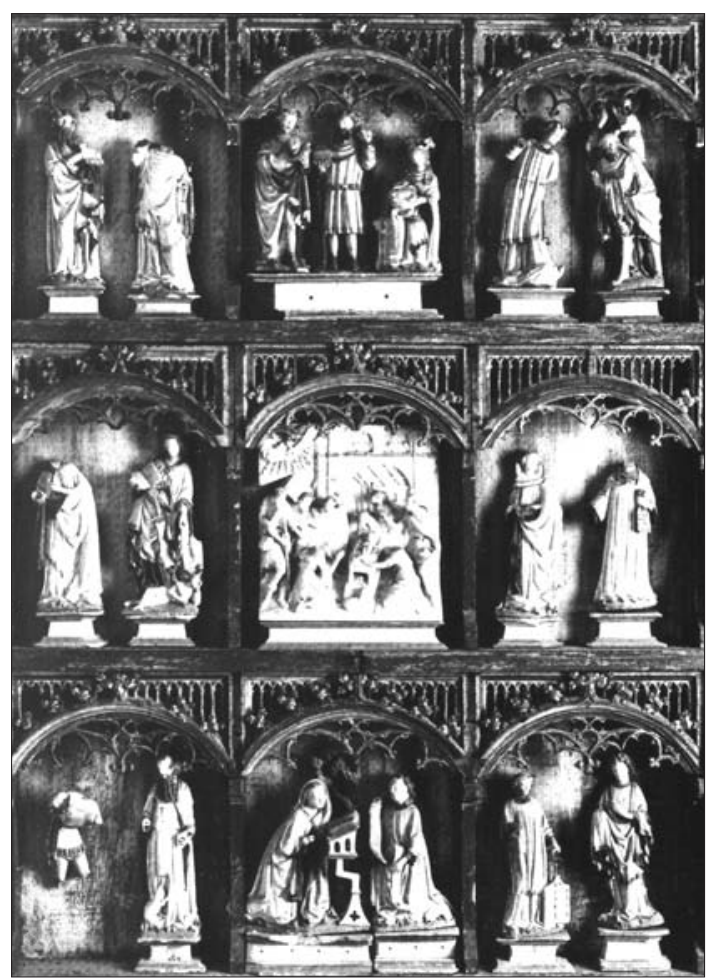

Fig. 1. Relicario con doce figuras de santos y escenas de la vida de la Virgen. Escuela del medio Rin.

Maestro de Rímini (ca. 1420), iglesia de Schwabstedt, en Treene. Relicario (148 x 110,5 x 138,5 cm.)

en madera de roble que contiene esculturas de alabastro de $25 \mathrm{~cm}$. de altura, aproximadamente.
Fig. 3. Virgen con Niño. Maestro de Rímini (ca. 1430). Alabastro. 18,95 cm. de altura. Sotheby`s Sale 7962. Jan 22, 2004. Lot. No. 159.

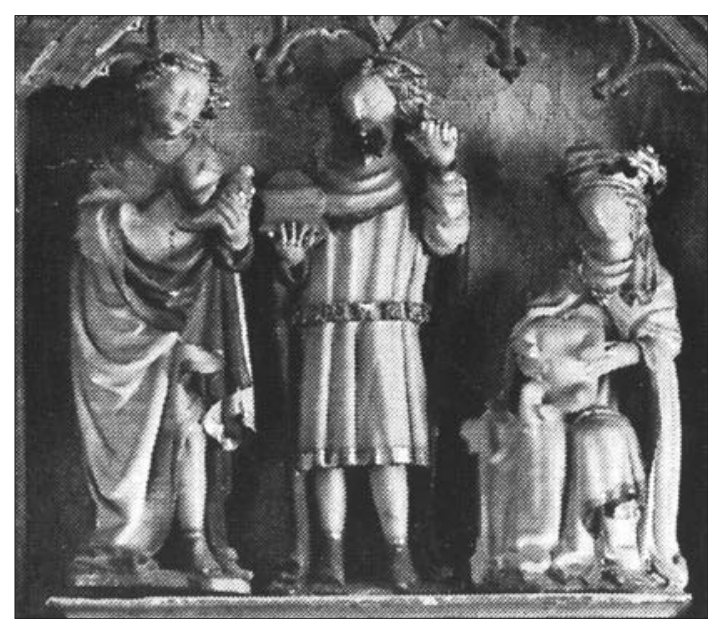

Fig. 2. Relicario con doce figuras de santos y escenas de la vida de la Virgen (detalle). "Virgen con Niño y dos reyes Magos". Escuela del medio Rin. Maestro de Rímini (ca. 1430), iglesia de Schwabstedt, en Treene.

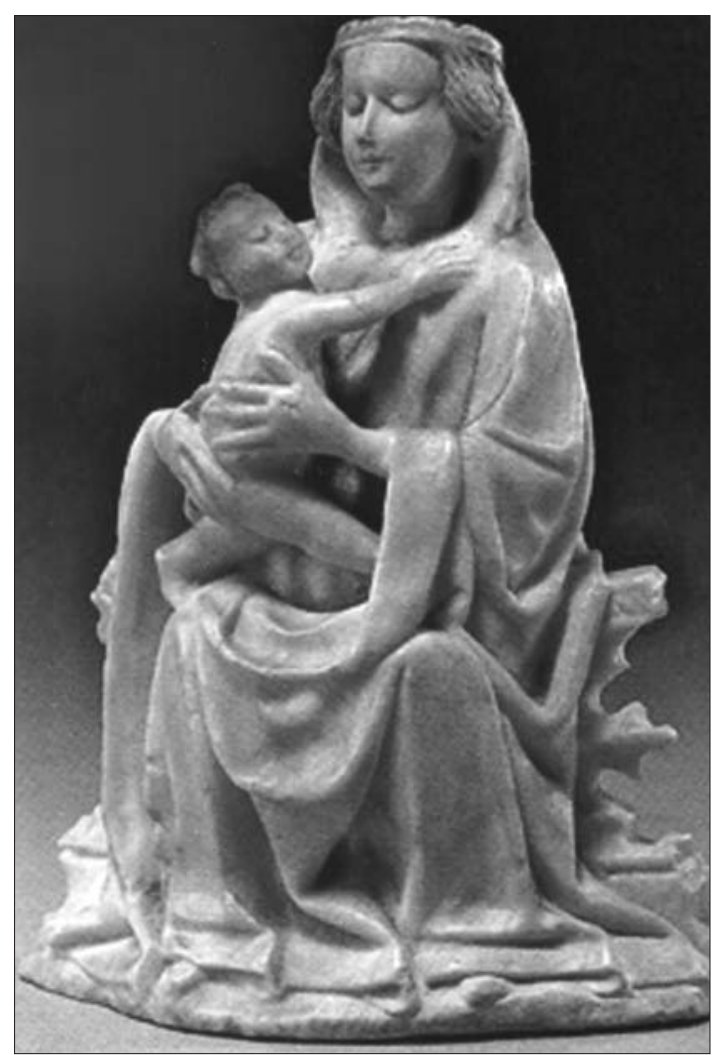


tensión interna define sus componentes esenciales, y ambas están unidas por una adecuada organización de los elementos integrantes y por una interacción física y emocional. De esta manera, el conjunto constituye una obra cuidadosamente tratada y de intensa carga emocional. La fusión de formas entre la Virgen y el Niño, aunque subraya sus distintas funciones, están vinculadas en su tácita comprehensión de la unión entre ambos seres y por el desenlace final del sacrificio de la humanidad para su Redención.

La impresión general de la escultura está sugerida por un cuidado drapeado de convulsos pliegos, por la austera lisura de las superficies redondeadas y por la sustitución de la uniformidad de filo y hondura por juegos excepcionales de huecos y sólidos. Todo ello concedió a la excelsa figura de la Virgen una belleza alzada y formal, al tiempo que fue resaltada la preciosidad del frágil y translúcido material, fuente de luz y sensibilidad, cuya suavidad suprime cualquier sensación de dureza y rigidez.

El leve giro hacia la derecha del cuerpo de la Virgen, originado por la posición de su pierna derecha, ligeramente más elevada que la izquierda ya que esta se coloca de manera más rígida, produce una sensación de elegante amaneramiento de la extraordinaria pieza. Al tiempo que esta organización en la perspectiva, en rotación externa y hacia la posición del Niño, gana en contorno y, debido a la amplia vestimenta, en masa y volumen.

Pero el elemento primario y decisivo, lo propio de la Virgen de la Peña, es la inocencia casi infantil de su rostro. También la huella del brazo y la débil mano -casi esbozada y muy esquemática- de la Virgen que abraza la cintura del Niño, materializa tanto la fragilidad de la expresión como la delicadeza inherente a esta obra afable que determina su etérea atmósfera y magia espiritual.

A pesar de su pequeño tamaño $(21 \times 15 \times 9 \mathrm{~cm}$.), el conjunto despliega un efecto plástico de gran intensidad al igual que todas las obras ejecutadas en los talleres del "Maestro de Rímini"; esta cualidad constituye, precisamente, una de las características propias del taller de alabastro, especializado, en este caso, como un lugar de producción de esculturas de reducido formato y la circunscribe a una pieza de devoción privada.

La talla de la Virgen entronizada es un producto más de la fecunda producción del estilo Gótico Internacional, adhiriéndose a una de sus variantes lingüísticas, al denominado "estilo suave" o "bello estilo", desarrollado entre 1400-1440, debido a su hermosura formal, a su juventud y serenidad, a su elegancia y sensibilidad, a la gracia y armonía de formas y, especialmente, a su rostro de expresión suave y de formas redondeadas. También destaca por esa brillante simbiosis entre realismo neerlandés y formalismo estético que parece subsistir en las esculturas góticas provenientes de estos territorios.

Posee ese grado de concentración espiritual en un cuerpo adaptado a un canon de total armonía por medio de la clara organización de los tejidos y la sutil formación de los enriquecedores plisados. En este sentido, mientras amplias cascadas de pliegos decoran ricamente la vestimenta de la imagen, parece que perviven al mismo tiempo una simplificación de la factura, pero todo permanece con rotundidad por el equilibrio existente entre figura y ropaje: una gradación de formas que radica, pues, en lo tectónico de la imagen.

El característico vestido que casi envuelve las formas físicas está constituido por un alba que cubre el pecho, ajustado en la cintura por un cíngulo en un plano articulado de pliegues desiguales y bien distribuidos verticalmente que manifiestan las formas más prominentes del vientre de la Virgen. La túnica está envuelta por un ampuloso gabán de amplias mangas enrolladas alrededor de sus brazos, caracterizado por su ritmo gradual que oscila desde lo suave a lo removido de los pliegues inferiores, y cubierto por una holgada capilla, una especie de capucha desplegada abiertamente por ambos lados cuyos extremos están anudados de forma sensible por debajo del cuello de la figura.

Es decir, las colgaduras y vestidos caen en pliegues generando contrapuntos de luz y sombra, volumen y vacío, revelando muy poco de la anatomía de la Virgen. Esta fluidez de las colgaduras, abiertas en la parte superior y más tupidas y complejas desde la cintura hacia abajo, es común en las obras del "Maestro de Rímini" ya que fueron ejecutadas con aquellas técnicas que habían 
sido utilizadas por los escultores de madera; procedimiento que indica, una vez más, las estrechas relaciones existentes entre las obras lígneas y las de alabastros.

Los plisados y huecos concéntricos desarrollados desde la mitad inferior de la figura caen al suelo, abanicándose en múltiples pliegues (fig. 5). De esta manera, las rodillas están unidas por dos pliegos claves en forma de arco que se unen en un dobladillo siguiendo el eje vertical de la composición; los dos remarcados pliegues en forma de "V" constituyen, también, un sello conceptual de las bellas madonnas del "estilo suave", vinculadas con los talleres del "Maestro de Rímini”.

A ambos lados, rozando prácticamente las geométricas molduras del trono, los pliegues en bolsillo forman trazados sinuosos o bien quebradizos (figs. 6 y 7); la inclinación de estos pliegos exteriores y su transcurso lateral, indican la orientación de la figura al tipo de pliegue simétrico. Por último, los ángulos de los tejidos cobran mayor intensidad en su caída desplomada, rompiéndose al tocar el suelo en pequeños pliegues ganchillos o corchetes y flotando de manera agitada sobre una base de escaso grosor e irregular por la que asoman tímidamente las puntas afiladas de los pies de la Virgen. Como antes se precisaba, aquellos pequeños y numerosos volantes, tallados con fina precisión y habilidad, constituyen referencias ineludibles de los modelos pictóricos, especialmente de las obras de Jan van Eyck, Roger van der Weyden, Maestro de Flèmalle y Robert Campin.

Así pues, las vestiduras absorben la forma física de la Virgen, dejando solamente al descubierto sus manos y cara para transmitir una estremecedora ternura espiritual y una delicadeza de sensibles formas. La Virgen entonces parece emerger de sus vestidos con una calma divina. El blando tratamiento de las manos y rostro, proporcionan a la escultura un grado de verismo y humanización, una autonomía de lo plástico propia del realismo neerlandés. Las formas suaves y redondeadas de la cara, sugieren por ello una serenidad que brota de una turbulencia abrumadora. Un rostro dulce y exquisito, de grave potencia artística y expresión máximamente concentrada, y al mismo tiempo ausente.

La cabeza está girada ligeramente hacia la derecha, en correspondencia con la figura, y caída levemente hacia abajo. Así tiene mayor identidad su exquisito rostro de facciones redondeadas, compuesto por una boca pequeña de labios apretados, un mentón ovalado, una nariz aguileña y unas cejas marcadas que delimita una aparente incompleta formación de los ojos, con los párpados caídos o cerrados, como ocurre con un conjunto de esculturas de alabastro del "Maestro de Rímini", que por esta singular característica se les asignó el calificativo de non finito ${ }^{52}$. Este rasgo distintivo no supone alguna imperfección técnica del tallado, acaso hace referencia a un cierto grado de abstracción figurativa, propias de las esculturas del momento, tanto ejecutadas en blancos alabastros como en nobles maderas.

La perspectiva del reverso de la imagen, menos conocida por su ubicación en el nicho central del retablo de su ermita, revela nuevos valores estéticos, como las líneas pronunciadas de los escasos y bien distribuidos pliegues, la suave modelación de la superficie y la posición de la mano izquierda del Niño, en un gesto íntimo y cariñoso (fig. 8). En esta parte de la imagen, los doblados de las vestiduras se distribuyen como baquetones de manera dispersa, tanto en la capilla como en el gabán, formando ejes verticales que se abren en los laterales, acentuando la volumetría y las texturas de la figura (fig. 9). Todo ello ejecutado con la técnica del tallado duro, lo que demuestra, otra vez, las estrechas conexiones que hubo entre los procedimientos escultóricos empleados por las tallistas de alabastro y madera. Por otro lado, estos esquemáticos pliegues sugieren, en cierta manera, los elegantes drapeados de las esculturas del arte cortesano de Borgoña y su área de influencia internacional.

52 Entre ellas: la "Madonna dell Aqua", en el templo Malasteniano de Rímini; la "Piedad", que figura en el célebre altar de Frankfurt; los "Ángeles de la Anunciación”, en el Museo La Chartreuse, en Douai; y otros ángeles del mismo tema, en el palacio Borromeo, en Isola Bella. Cfr. Legner: art. cit., pp. 101-168. 


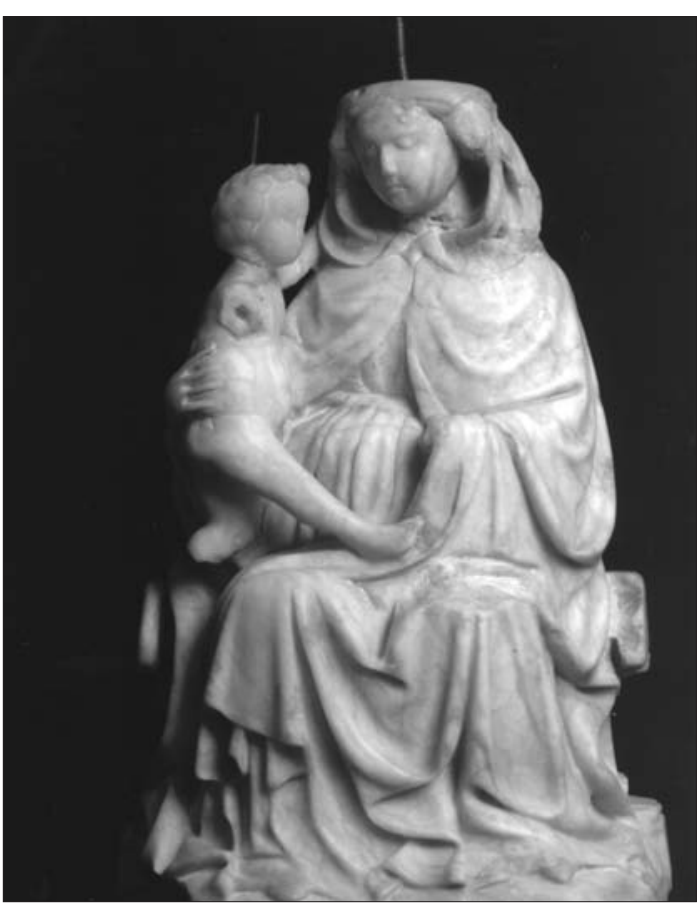

Fig. 4. Virgen de la Peña. Maestro de Rímini (ca. 1400-30). Alabastro (21 x 15 x $9 \mathrm{~cm}$.). Santuario de Nuestra Señora de la Peña, en Vega de Río Palmas (Betancuria). Isla de Fuerteventura (Canarias). Foto C. de Saá.



Fig. 5. Virgen de la Peña (detalle). Tratamiento del drapeado en pliegues centrales en forma de "V", abanicados en múltiples dobladillos. Foto C. de Saá.

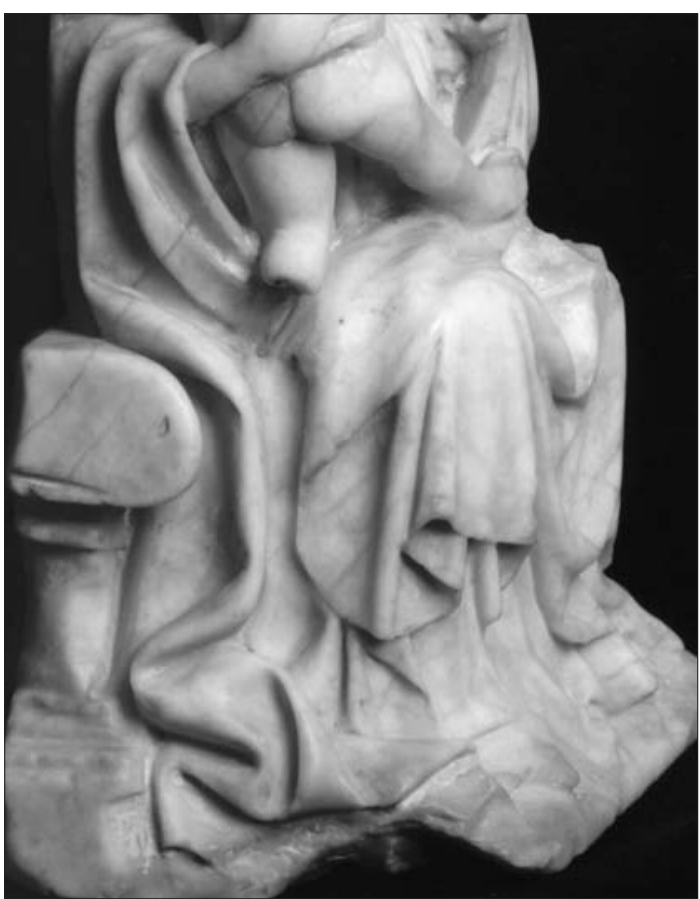

Fig. 7. Virgen de la Peña (detalle). Pliegues laterales quebradizos y pliegues ganchillos o corchetes en el zócalo. Foto C. de Saá.

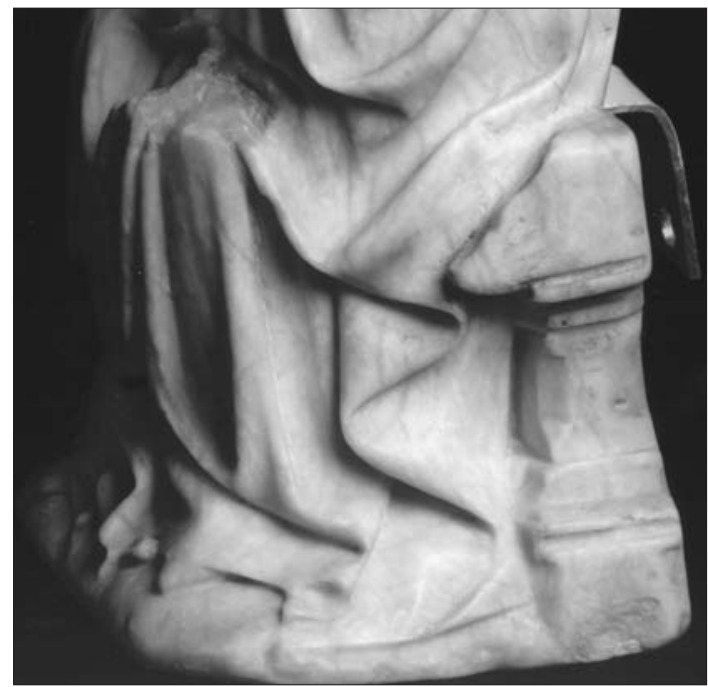

Fig. 6. Virgen de la Peña (detalle). Pliegues laterales sinuosos en bolsillo. Foto C. de Saá. 
En este lado, el banco no estaba destinado para ser visto, por ello está excavado en forma de un amplio hueco en el mismo bloque de alabastro con la finalidad de adaptar la escultura a una caja, probablemente de madera, para su protección y cómodo transporte. No hay que olvidar que es una obra de devoción y de las llamadas "esculturas de viaje" ya que fueron trasladadas a gran escala por vía marítima o continental desde los talleres de origen al resto de Europa. Esta oquedad en el reverso del trono de la Virgen de la Peña, la posee también muchas esculturas de alabastro del siglo XV, entre ellas, las conocidas Anunciaciones de París y Londres.

La figura de Niño está colocada en posición lateral, siguiendo una dirección opuesta a la de la Virgen. El ágil posicionamiento de sus piernas entreabiertas, en ángulo, en una postura casi circense, constituye una pieza fuertemente individualizada en el grupo, definiendo así transiciones melifluas en la composición y una integración armónica en el conjunto. La escultura está muy deteriorada, tiene mutilaciones y la cabeza es un añadido posterior 53 .

\section{Analogías de la Virgen de la Peña con otras esculturas del Maestro de Rímini}

Naturalmente, al constatar la existencia de la Virgen de la Peña como una escultura que es producto de la abundante producción de los talleres de alabastros del siglo XV, y fabricada en "serie" como objeto de devoción privada, se podrían registrar varias analogías con otras esculturas del "Maestro de Rímini", tanto de identidad estilística como tipológica. Algunas de estas concordancias han sido tratadas en las páginas anteriores, pero ahora se procura establecer igualdades formales con mayores afinidades.

En lo que hace referencia a las esculturas de igual iconografía que sostienen concomitancias con la Virgen de la Peña, habría que citar en primer lugar, por orden cronológico, la Virgen con Niño, integrada en la calle central del cuerpo superior del Relicario con escenas de la Vida de la Virgen y con doce figuras de santos, en la iglesia de Schwabstedt, en Treene (figs. 1 y 2) ${ }^{54}$, cuya excelente calidad confluye en la juventud del rostro de la Virgen y en los sensibles y amplios pliegues curvados, características genuinas de las "bellas vírgenes" del norte de Alemania y del "estilo suave" de los Países Bajos meridionales.

La Virgen con Niño (fig.3), localizada en la colección Sotheby`s ${ }^{55}$, claramente derivada de las influencias de los viejos maestros de la pintura, cuya disposición de la Madre sedente, con ese controlado giro hacia la derecha, así como sus envolturas sueltas y despejadas, y los plegados centrales en forma de "V", es, salvo escasos matices diferenciales, prácticamente similar a la patrona de Fuerteventura.

53 ADC (Archivo Diocesano de Canarias). Libro de Fábrica de la ermita de Nuestra Señora de la Peña. En el inventario de la ermita, efectuado el 22 de noviembre de 1600, se precisa que el Niño está sin cabeza y un pie menos... (folio 14); aún figuraba en el mismo estado en 1656, según se anota en el inventario de 24 de abril. Sin embargo, en el registro de bienes de 8 de febrero de 1678, puede deducirse que el Niño ya está reparado, pues en esa fecha se le regala una coronita imperial de plata... (folio 81). Quizás, la frágil talla de alabastro se deterioró durante la invasión del arráez Xabán en 1593, al objeto de custodiarla en una cueva próxima para protegerla del saqueo berebere. También es probable que debido a este suceso, la Virgen perdió gran parte de su policromía.

54 Véase nota 49. Altura media de la figura: $25 \mathrm{~cm}$. de altura, al igual que todas las esculturas que forman el conjunto del relicario. Los temas iconográficos, además de los santos mártires, son los siguientes: compartiendo escena con la citada "Virgen con Niño" figuran "dos Reyes Magos"; en los cuerpos inferiores de la misma calle, aparecen, de abajo hacia arriba, la "Anunciación" y la "Adoración de los Pastores". El relicario (148 x 110,5 x 13,8 cm.) donde están integradas todas las esculturas, es de madera de roble, también con restos de policromía y sobredorado.

55 Escuela de Rímini, ca. 1430. Alabastro. Medidas: 18,95 cm. de altura. Sotheby`s Sale 7965. Jan 22, 2004. Lot. $N^{\circ}$. 159. Cfr. Husband, B.: "Tilman Riemenschneider and the tradition of alabaster carving", en Simposium Tilman Riemenschneider: A late Medieval Master Sculptor", 3-4 december (1999), Washington. Pricenton. Editorial Associates, Yale University Press, New Haven y Londres, 2004. 


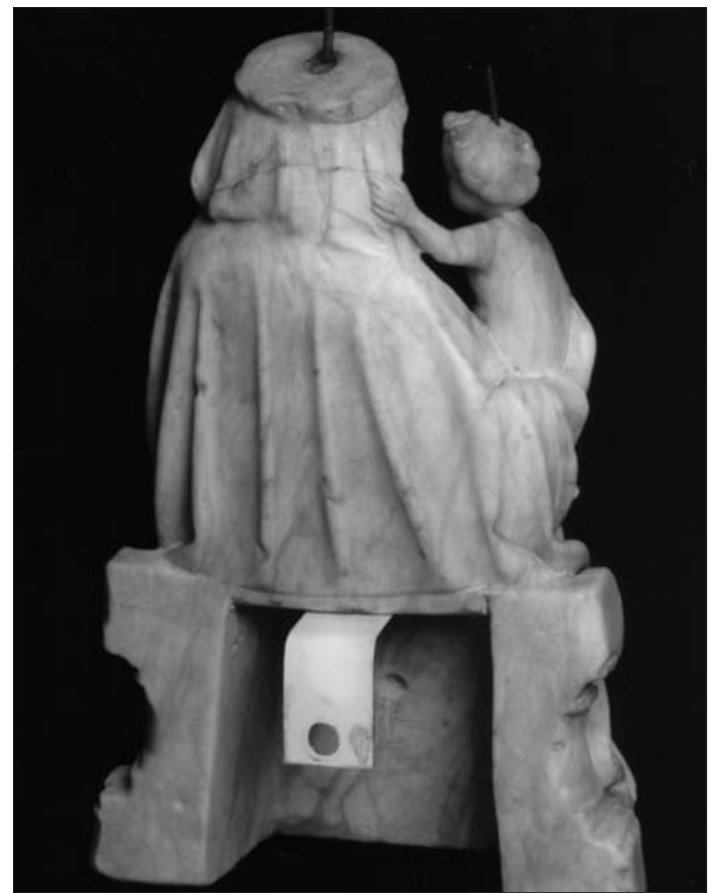

Fig. 8. Virgen de la Peña. Reverso de la figura y oquedad en la base para acomodarla a una "caja de viaje". Foto C. de Saá.

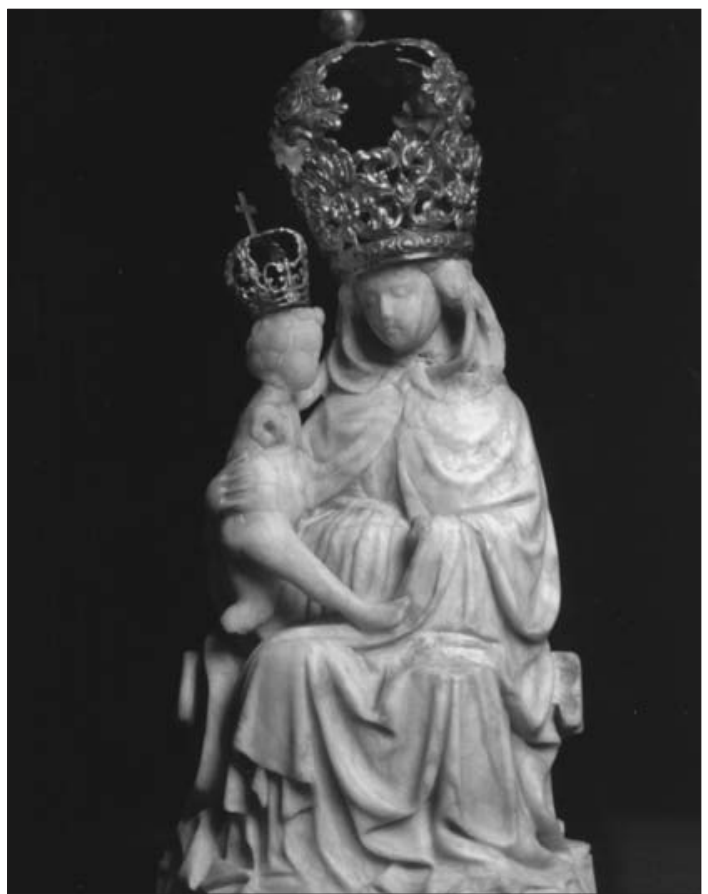

Fig. 10. Virgen de la Peña engalanada con las coronas imperiales. Foto C. de Saá.

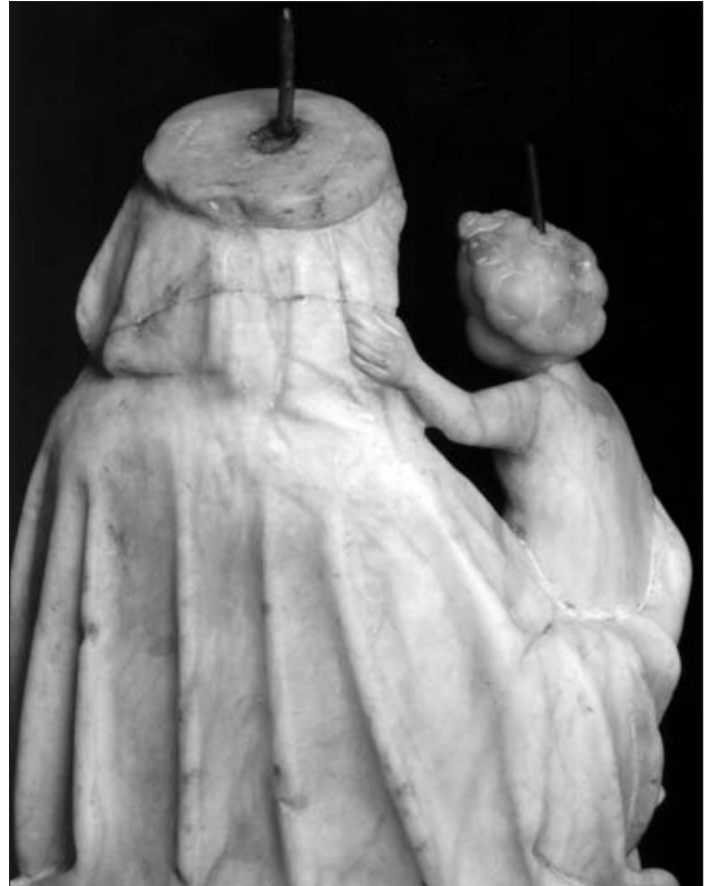

Fig. 9. Virgen de la Peña (detalle del reverso de la figura). Pliegues del gabán y de la capilla. Foto C. de Saá.

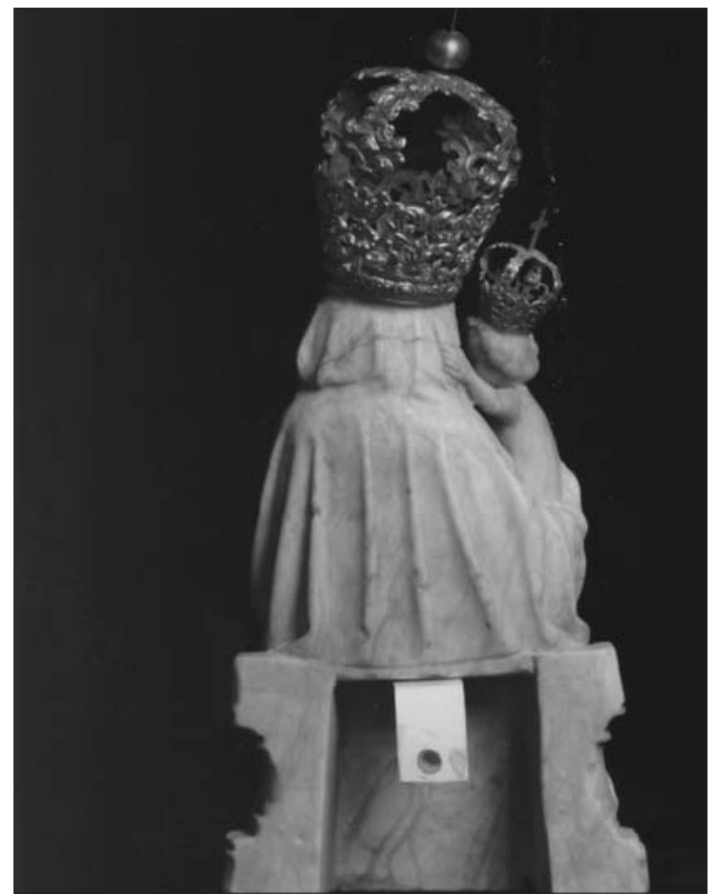

Fig. 11. Virgen de la Peña. Reverso de la obra. Foto C. de Saá.

AEA, LXXX, 318, ABRIL-JUNIO 2007, 141-160, ISSN: 0004-0428 
La Virgen entronizada con Niño, depositada en la galería Neuse, en Bremen ${ }^{56}$. Aunque de mayor dinamismo que la Virgen de la Peña en la composición general, anótense como igualdades la agitación del drapeado, con los característicos doblados concéntricos en forma de "V" que se despliegan en ganchillos en la parte inferior de la bellísima madonna, cuyo cabello y rizado evoca aquellas exquisitas vírgenes de Roger van der Weyden.

En el ámbito de las igualdades estilísticas entre la Virgen de la Peña y otras esculturas de alabastros del mismo periodo, se pueden indicar, entre otros, los siguientes exponentes. En la Virgen de la Anunciación, en Clerques, proveniente de la iglesia de saint-Barthèlèmy, en la misma ciudad $^{57}$, se pueden establecer como rasgos comunes, el ritmo sinuoso de la composición, la delicadeza y serenidad del rostro de la Virgen y los plegados que fluyen con armonía y naturalidad. La Piedad que, procedente de la galería Christies, en Londres, fue adquirida en el mercado del arte de Würzburg 58 ; constituye una de las iconografías predilectas en los antiguos Países Bajos, cuyo prototipo de alabastro más antiguo es el Conjunto de Eitelsbach, exhibido en el Museo Diocesano de Traer. Aunque uno de los ejemplos más severos y elegantes es el conservado en el Museo Victoria y Alberto; la figura dolorosa de María está tallada con suaves formas redondeadas, rostro oval de pequeñas proporciones, como las esculturas propias del "estilo suave", y pliegues finalmente modulados. Además, el reverso del banco está excavado al objeto de que fuese adaptada en una caja para su seguro transporte. Y un Ángel arrodillado, en el Museo de Douai ${ }^{59}$, cuyo origen se ha situado en un área cercana a Tournai-Lille, zona en la que se han encontrado escasos testimonios de esculturas de alabastros correspondientes al gótico tardío por lo que constituye una obra de enlace muy importante en la producción de alabastro de las primeras décadas del siglo $\mathrm{XV}$; debido a la ingenua expresión de su rostro se le ha igualado con la escultura de san Quintín, calificada como originaria de Westfalia ${ }^{60}$.

Esta misma iconografía se encadena con la elegantísima pieza de igual nombre conservada en el Metropolitan Museum, de configuración similar al san Juan y a la María Magdalena correspondientes al Altar de Rímini instalado en el Liebieghaus de Frankfurt. Ambas obras, muy expresivas, al tiempo que emotivas y conmovedoras, muestran estudiados drapeados y exquisitas facciones de los rostros con la particular característica del tallado de los ojos con los párpados caídos, con esas miradas ausentes hacia el non finito, al igual que la Virgen de la Peña.

\footnotetext{
56 Escuela del medio o bajo Rin. Segundo cuarto del siglo XV. Alabastro con huellas de policromía y sobredorado. Medidas: 17,2 cm. de altura. Galería Neuse, Bremen. Catálogo: 19. Westdeustsche Kunstemesse, Düsseldorf, 1988, figura p. 187.

57 Entorno del Maestro de Rímini, ca. 1425-30. Alabastro. Medidas: 61×20 x14 cm. Bibliografía: AA. VV.: (Aniick Notter, recopilación de textos): "La sculpture de gothique tardif en Artois (1430-1530)", en Fragments d'une Splendeur. Arras à la fin du Moyen Age. Museè des Beaux-Arts d'Arras, 2000. Al pie del texto, figuran las siglas de los autores del mismo (F. B y J. S.), figura, 122, p. 111.

58 Maestro de Rímini. Países Bajos meridionales (¿), alrededor de 1440. Alabastro con restos de policromía original en los pliegues del gabán. Medidas: 26,5 cm. de altura. Procedencia: Galería Christies, en Londres. Subasta con fecha 18-04-89. P1990/13, tabla VII. Bibliografía: Sawarzenski, G.: "Deustshe alabasterplastik des 15. Jahrhunderts"..., pp. 167-213; Krautheimer, R.: Lorenzo Ghiberti..., pp. 62-67 y pp. 353-357; Wackenroder, E. y Neu, E.: Die Kunstdenkmäler des Landkreises Traer. Dusseldorf, 1936, pp. 349-350; Legner, A.: "Der alabasteraltar aus Rimini..., pp. 101168; Kutal, A.: "Les problèmes limitrophes de la sculpture Tchèque au tornant 1400"..., pp. 5-23, en Europäische Kunst um 1400. Ausstellungskatalog. Viena, 1962; The international style. The arst in Europe around 1400. Ausstellungskatalog. Baltimore, 1962, Nr. 99, p. 98; Bouvy; D.: Beeldhouwkunst. Aartsbisschoppelijk Museum Utrecht, 1962, Nr. 29, pp. 41-42; Didier, R. y Krohm, H.: "Les sculptures medievales Allemandes dan les colecctions Belges". Ausstellungskatalog, Bruselas, 1977, Nr.15, pp. 37-39; Fabian, G.: Betandskataloge des Mittelrhein-Museums Koblnez. Die Skulpturen vom 12. bis 18. Jahrhundert. Band III. Herausgegeben von Klaus Weschenflder. Koblenz, 1993, Nr. 23, pp. 60-61.

59 Walter Paatz sitúa el origen estilístico del “Altar de Rímini” en un área próxima a Tournai-Lille, al igual que el "Ángel” del Museo de Douai.

60 Sawarzenski, G.: "Deustshe alabasterplastik des 15. Jahrhunder.
} 
Aunque la imagen de Fuerteventura es una escultura extraordinaria, como hemos visto, su estado de conservación es preocupante ya que presenta mutilaciones y desperfectos de importancia, así como acumulaciones de colas alteradas y materias grasas. Excede los límites del presente estudio pormenorizar todas estas deficiencias que merman la contemplación de la escultura y señalan la débil protección de nuestro legado histórico y cultural. Pero, por otro lado, al examinar la obra se perciben restos de estucos poblando varias zonas de la superficie de la Virgen, revelando que la imagen tuvo policromía, desaparecida, quizás, en las intervenciones posteriores de la talla o a la inadecuada protección de la escultura, o por ambos motivos. En este sentido, es probable que debido a la invasión de la Villa de Betancuria del arráez Xabán, en 1593, la escultura fuese resguardada en algún lugar impropio durante un largo periodo para protegerla de las hordas berberiscas, suceso que afectaría al primitivo estado de la frágil talla.

En este campo de estudio, es necesario precisar que una gran número de esculturas de alabastro del siglo XV, varias de ellas realizadas en los talleres del "Maestro de Rímini", fueron policromadas total o parcialmente con base a tintes azules y redes de oro sobre los bordes de los mantos y los vestidos de las vírgenes y, a veces, los labios de las agraciadas figuritas eran relucidos con vibrantes rojos. En general, las pequeñas esculturas de devoción para el uso doméstico se fabricaron bien policromadas o sin policromar, y en ocasiones engastadas, todo ello según el gusto del comprador, y en algunos casos fueron policromadas una vez instaladas, como lo demuestran varios ejemplos salidos de los talleres de Arras. Es muy probable, pues, que la Virgen de la Peña haya sido engalanada, con toda su brillantez y esplendor, por medio de la aplicación de estos valores cromáticos, aunque quizás solo en determinadas zonas de la talla con el objeto de que la selecta belleza del material constituyese la válida expresión de la forma (figs. 10 y 11)

En cualquier caso, la Virgen de la Peña que hoy se encuentra presidiendo el retablo de su ermita, en la Vega de Río Palmas, en Betancuria, constituye una encantadora escultura fruto de la permeabilidad de la cultura europea propia de aquella época, siendo producto de los talleres de alabastros más prolíferos del momento; un pieza más entre una serie de obras adscritas al arcano "Maestro de Rímini”". 